\title{
Steam reforming ofbiomasstar over calcined egg shell supported catalysts for hydrogen production
}

Jingxuan Yang ${ }^{1,2, \#, ~ M a l i n e e ~ K a e w p a n h a, ~}{ }^{3, \#}$, Surachai Karnjanakom ${ }^{3}$,Guoqing Guan ${ }^{1,3^{*}}$,Xiaogang $\mathrm{Hao}^{2}$, Abuliti Abudula ${ }^{1,3}$

${ }^{1}$ North Japan Research Institute for Sustainable Energy (NJRISE), Hirosaki University, 2-1-3 Matsubara, Aomori 030-0813, Japan

${ }^{2}$ Department of Chemical Engineering, Taiyuan University of Technology, Taiyuan 030024, China

${ }^{3}$ Graduate School of Science and Technology, Hirosaki University, 1-Bunkyocho, Hirosaki 036-8560, Japan

${ }^{*}$ Corresponding author:

Tel.: +81 17762 7756; E-mail: guan@hirosaki-u.ac.jp (G. Guan)

"These authors contributed equally to this work. 


\begin{abstract}
Calcined egg shell (CES) shows porous structure and exhibits alkaline property, which is expected to be applied for the adsorption and decomposition of biomass-derived tar. In this research, steam reforming of tar derived from cedar wood over CES was firstly investigated in a fixed bed reactor and found that CES had high catalytic activity for steam reforming of tar to produce hydrogen-rich gas. Then, iron, nickel, cobalt and copper were loaded on CES, more syngasespecially hydrogen gas was produced. Among them, copper loaded CES exhibited more enhanced catalytic activity. The optimum Cu loading amount on CES was found to be $1-2 \mathrm{wt} \%$, which resulted in the most amount of syngas and exhibited excellent reusability.
\end{abstract}

Keywords: Biomass; Hydrogen production; Catalytic steam reforming; Egg shell;Copper. 


\section{Introduction}

Recently, biomass has gained greatattention because of its renewability. Thermochemical conversion of biomass to gas, liquid and solid fuels is an effective way for utilization of biomass energy. Among the thermochemical conversion processes, gasification one can convert biomass into syngas, whichcan be used for the synthesis of methanolvia catalytic reaction, the production of liquid fuels viaFischer-Tropsch synthesis process, and the generation of electricity via turbine, gas engine or fuel cell [1,2]. However, in the gasification process, a large amount of tar is generally cogenerated with syngas, resulting in gas-line blockage and even the system stopped suddenly in many cases. Therefore, it is necessary to reduce the tar generation and/or effectively remove it from the syngas.

To date, although some novel methods such as using gliding arc plasma [3,4] have been developed for the conversion of tar into syngas, most researches still focus on thecatalytic steam reforming of tar, in which the key is to findhigh active catalysts with low cost. Alkali andalkaline earth metals (AAEM)such asCa,Mg,Kand Na, which are widely existed in natural resources such asbiomass ash, biomass char, dolomite,and waste scallop shellhave beenfound to have high catalytic activity for thetar reforming[5-9].Besides, various transition metal catalysts such as $\mathrm{Fe}$, $\mathrm{Co}$ and $\mathrm{Ni}$ and noble metal catalysts also show high catalytic activity [5,10-15].To improve the catalyst 
stability,some researchers mixed varioustransition metalsor supported them on the porous materials [16-22].Li et al. [23] supported $\mathrm{Co}$ on $\mathrm{BaAl}_{12} \mathrm{O}_{19}(\mathrm{BA})$ and found that $\mathrm{Co} / \mathrm{BA}$ catalyst had significantly higher activity in tar reforming when compared withCo supported on $\mathrm{Al}_{2} \mathrm{O}_{3}, \mathrm{ZrO}, \mathrm{SiO}_{2}, \mathrm{MgO}$ or $\mathrm{TiO}_{2}$. Because of the excellent $\mathrm{CO}_{2}$ capture capability and low cost, $\mathrm{CaO}$ is applied as catalyst or catalyst support for tar removal.D’Orazio et al. [24] and Zambomi et al. [25]separatelyreported that the combination of $\mathrm{Ni}$ and $\mathrm{Fe}$ with $\mathrm{CaO}-\mathrm{Ca}_{12} \mathrm{Al}_{14} \mathrm{O}_{33}$ resulted in high catalytic activity for the steam reforming of tar and water gas shift reaction. Similarly, Ni loaded Mayenitewas found to have high activity for conversion of biomass tar into hydrogen-rich gas in fluidizedbed steam gasificationprocess, and the conversion rate reached $90 \%$ at $800^{\circ} \mathrm{C}$ with a long-term stability[26]. Moreover, Ashokand Kawireported that the addition of $\mathrm{CeO}_{2}$ promoted the formation ofNi-rich surface in $\mathrm{Ni} / \mathrm{CaO}-\mathrm{Al}_{2} \mathrm{O}_{3}$ catalyst, which results in higher catalytic activity and carbon resistance[27].

In our previous studies[7-10],metal loaded on variouslow-cost resources such as waste scallop shell and biomass/coal char were successfully utilized for the steam reforming of tar derived from biomass to produce hydrogen-rich gas. Likewaste scallop shell and biomass/coal char, egg shell is an abundant waste resource containing plenty of calcium element. In the present study, the calcined egg shell (CES) was used as catalyst and catalyst support for the steam reforming of tar. Various metals such as $\mathrm{Fe}, \mathrm{Ni}$, $\mathrm{Co}$ and $\mathrm{Cu}$ 
were loaded on it to improve the catalytic activity, and the effect of metal loading amount on the catalytic activity was investigated. For the best obtained catalyst, its catalytic stability and reusability were also tested. It is expected to obtain a reliableand low-cost catalyst with high activity and long-term stabilityfor the steam reforming of biomass tar.

\section{Experimental}

\subsection{Biomass}

In this study, cedar wood with a size of $1-2.8 \mathrm{~mm}$ was used as biomass feedstock, which was dried at $110^{\circ} \mathrm{C}$ overnight before storage and further use. The final water content in itwas about 8 wt\%. The water-free element compositions by weight percentage of it were C 48.8 wt\%, H 6.6 wt\%, O 43.0 wt\%, N 1.4 wt\% and ash 0.2 wt\%.Based on XRF analysis (Energy Dispersive X-Rayspectrometer EDX-800HS, Shimadzu), 0.8wt\% $\mathrm{Fe}_{2} \mathrm{O}_{3}, 50.68$ wt\% $\mathrm{CaO}, 4.1 \mathrm{wt} \% \mathrm{~K}_{2} \mathrm{O}$, and $0.04 \mathrm{wt} \% \mathrm{SrO}$ were found in the ash.

\subsection{Catalyst preparation and characterization}

Egg shell was firstly washed several times and dried at $110^{\circ} \mathrm{C}$ for $24 \mathrm{~h}$, and then, it was crushed and sieved to $<250 \mu \mathrm{m}$ particle size before calcination in air at $900^{\circ} \mathrm{C}$ for $2 \mathrm{~h}$. Based on the preliminary experiments, $1 \mathrm{wt} \% \mathrm{Fe}-$, Ni-, Co and $0.25-10 \mathrm{wt} \% \mathrm{Cu}$ were respectively supported on the calcined egg shell (CES) by using the incipient wetness impregnation 
method, in which a mixed aqueous solution of $\mathrm{Cu}\left(\mathrm{NO}_{3}\right)_{2} \cdot 3 \mathrm{H}_{2} \mathrm{O}$ (Sigma-Aldrich Japan), $\mathrm{Fe}\left(\mathrm{NO}_{3}\right)_{3} \cdot 9 \mathrm{H}_{2} \mathrm{O}$ (Sigma-Aldrich Japan), $\mathrm{Ni}\left(\mathrm{NO}_{3}\right)_{2} \cdot 6 \mathrm{H}_{2} \mathrm{O} \quad$ (Sigma-Aldrich Japan), $\mathrm{Co}\left(\mathrm{NO}_{3}\right)_{2} \cdot 6 \mathrm{H}_{2} \mathrm{O}$ (Sigma-Aldrich Japan) was used. After impregnation and aging for approximately $2 \mathrm{~h}$, the slurry was dried overnight at $110^{\circ} \mathrm{C}$, and then, the dried powders were calcined in air at $650^{\circ} \mathrm{C}$ for $3 \mathrm{~h}$. As a reference, commercial $\mathrm{CaO}$ (Nacalai Tesque Inc., Japan) was also used as the catalyst as well as the catalyst support.

Surface morphology of catalyst was characterized with a scanning electron microscope (SEM, SU8010, Hitachi, Japan) coupled with energy dispersive X-ray detector (EDX). The crystal structure of as-prepared catalyst was determined by using RIGAKU Smartlab X-Ray diffractometer (XRD) with $\mathrm{Cu} \mathrm{K}_{\alpha}$ radiation $(\lambda=0.154 \mathrm{~nm})$ generated at $45 \mathrm{kV}$ and $200 \mathrm{~mA}$.

\subsection{In-situ catalytic steam reforming experiment}

In this study, in-situ catalytic steam reforming of tar derived from cedar wood was performed in a fixed bed, which was illustrated elsewhere[10].In short, about $0.6 \mathrm{~g}$ of cedar particle was put on the upper side of catalyst layer with a weight of $2.0 \mathrm{~g}$, and a thin layer of quartz wool was used to separate them. As such, the tar derived from the cedar wood can be carried with a gas flow and enter the catalyst layer.During the experiment, $0.09 \mathrm{~g} / \mathrm{min}$ of water was heated to about $250{ }^{\circ} \mathrm{C}$ and carried by50 $\mathrm{cm}^{3} / \mathrm{min}$ of $\mathrm{Ar}$ into the fixed bed reactor. 
The reactor was heated to $650^{\circ} \mathrm{C}$ with a heating rate of $20{ }^{\circ} \mathrm{C} / \mathrm{min}$, and the pyrolysis of cedar wood and the steam reforming of tar derived from it were carried out at the same conditions.Thus, the tar derived from the pyrolysis of cedar was carried by steam-Ar gas flow and passed through catalyst layer, wherethe steam reforming of tar occurred. The outlet gas wascooled down by two ice-bath condensers and then filtered by a dry $\mathrm{CaCl}_{2}$ column and collected in a gas bag. The reaction time was fixed at $2 \mathrm{~h}$ for each experiment. Agilent 7890A gas chromatograph systemwas used for the gas analysis.

\section{Results and discussion}

\subsection{Catalyst characterization}

Figure 1 shows XRD patterns of original egg shell andCES at different temperatures. SinceCaCO ${ }_{3}$ is the main component in egg shell, as shown in Fig.1, by calcining it at $800^{\circ} \mathrm{C}$ for $2 \mathrm{~h}$, peaks of $\mathrm{CaO}$ and $\mathrm{CaCO}_{3}$ can be simultaneously detected, indicating thata part of $\mathrm{CaCO}_{3}$ has been transformed to $\mathrm{CaO}$ at this temperature.After calcined it in air at $900{ }^{\circ} \mathrm{C}$ for $2 \mathrm{~h}$, only the peaks of $\mathrm{CaO}$ can be observed, suggesting that all $\mathrm{CaCO}_{3}$ in the egg shell has converted to CaO.Fromthe TGA result of egg shell sample (Fig.2),at the decomposition temperature ranged around 100 to $550{ }^{\circ} \mathrm{C}$, water and other organic protein molecules in egg shell structure are removed at first. Then,a significant weight loss (39 wt.\%) is clearly observed at a temperature range of about 600 to $800{ }^{\circ} \mathrm{C}$, resulting from the transformation 
of the $\mathrm{CaCO}_{3}$ to $\mathrm{CaO}$ with releasing of $\mathrm{CO}_{2}$. When the temperature is higher than $800^{\circ} \mathrm{C}$, no significant mass decrease can be observed, indicating that most of $\mathrm{CaCO}_{3}$ has transformed to $\mathrm{CaO}$. In general, the thermal decomposition of pure $\mathrm{CaCO}_{3}$ takes place at about 825-896. $6^{\circ} \mathrm{C}$. Therefore, in this study,the calcination temperature at $900{ }^{\circ} \mathrm{C}$ is enough to transform egg shell to $\mathrm{CaO}$ as indicated in Fig.1. Otherwise, based on the measured XRD patterns, the crystallite sizes of CaOin CES obtained at800 and $900^{\circ} \mathrm{C}$ are 82.8 and 106.9 $\mathrm{nm}$, respectively, indicating thatthe crystallite size increases with the increase in calcination temperature.XRF analysis indicates that the compositions of CES areCaO $98.7 \mathrm{wt} \%, \mathrm{SO}_{3}$ $0.8 \mathrm{wt} \%, \mathrm{~K}_{2} \mathrm{O} 0.4 \mathrm{wt} \%$ and $\mathrm{SrO} 0.1 \mathrm{wt} \%$.

Figure3shows SEM images of egg shell before and after calcination at $900^{\circ} \mathrm{C}$. One can see that by calcined at $900^{\circ} \mathrm{C}$, CES shows amacroporous structureon the surface(Fig.3 (b)), which should be benefit for the catalyst as well as catalyst support. BET measurementindicates that the BET surfacearea is only about $3.834 \mathrm{~m}^{2} / \mathrm{g}$ with a pore size of $4.21 \mathrm{~nm}$.

\subsection{Catalytic performance of CES}

Figure 4 shows the gas yields by using CES as catalyst which are compared with the cases by using the commercial $\mathrm{CaO}$ and without catalyst. One can see that the gas yields increase obviouslyin the presence of catalyst. Generally, steam reforming of tar can be 
expressed as[29, 30]:

$\mathrm{C}_{x} \mathrm{H}_{y} \mathrm{O}_{z}+(x-z) \mathrm{H}_{2} \mathrm{O} \rightarrow x \mathrm{CO}+(x+y / 2-z) \mathrm{H}_{2}$

At the same time, the water-gas shift (WGS) reaction will occur with the excess steam:

$\mathrm{CO}+\mathrm{H}_{2} \mathrm{O} \rightarrow \mathrm{CO}_{2}+\mathrm{H}_{2}$

In addition, $\mathrm{CH}_{4}$ is always detected, which should mainly come from the pyrolysis of biomass even without any catalyst.Here, it should be noted that the produced $\mathrm{CO}_{2}$ could be reacted with $\mathrm{CaO}$, which will result in the decrease of $\mathrm{CO}_{2}$ partial pressure in the system and promote WGS reaction to go forwards.Moreover, the enhanced WGS reaction will decrease the CO partial pressure in the system, which could promote tar reforming reaction. That is why more $\mathrm{H}_{2}$ and $\mathrm{CO}_{2}$ and less $\mathrm{CO}$ are detected in the presence of $\mathrm{CaO}$ catalyst.

When compared with the case without catalyst, one can see that the hydrogen yield in the presence of CES increases 4.9 times, but only 3.7 times for the commercial CaO.Forthe commercial $\mathrm{CaO}$,it is difficult to find macropore structure on it, and BET measurementindicates that its surface area is only $2.16 \mathrm{~m}^{2} / \mathrm{g}$ [28], which is also smaller than that of CES calcined at $900{ }^{\circ} \mathrm{C}$.Although surface areas of both are not so high, the textural property of CES should be more benefit for the reaction. Furthermore, it should be noted that some other trace metal species in CES should also have somecatalytic promoting effects on the reactions.As indicated above,besides $\mathrm{CaO}$, little amounts of $\mathrm{K}_{2} \mathrm{O}$ and $\mathrm{SrO}$ are also contained in CES . It has been proved that alkali metallic species such as $\mathrm{K}$ on $\mathrm{CaO}$ 
can enhance the absorption of $\mathrm{CO}_{2}$ and promote the WGS reaction[31-34].

\subsection{Metal-loaded CES catalyst}

In our previous work [7-10, 35-36],various metalswere loaded on calcined scallop shell or commercialzeolitefor the decomposition of the biomass-derived tar. It is found that the loading of metals on these supports can enhance the catalytic activity greatly. In this study, to investigate the effect of metal type on the catalytic activity, $1 \mathrm{wt} \% \mathrm{Ni}$, Co, $\mathrm{Fe}$ and $\mathrm{Cu}$ wererespectively supported on CESat first for the reforming of tar.As shown in Fig.5, it can be seen that the doping of metal on CES obviously promotes the yield of $\mathrm{H}_{2}$ while the yields of $\mathrm{CO}_{2}, \mathrm{CH}_{4}$ and $\mathrm{CO}$ are almost unchanged. It is reported that the tar could be adsorbed on metal crystallite sites as well as on CaO.Simultaneously,water moleculescan bealso adsorbed on $\mathrm{CaO}$. As such, $\mathrm{H}_{2}$ could be produced via dehydrogenation of adsorbed tar which could react with the back-spillover of labile $-\mathrm{OH}, \mathrm{H}$ and $-\mathrm{O}$ species onthe catalyst support as well as the metal active sites[37, 38].It should be noted that $\mathrm{H}_{2}$ yieldsin the presence of different metal loaded catalysts are different. The $\mathrm{H}_{2}$ yield from nickel- or cobalt-loadedCESare almost the same, which is higher than that from iron-loadedone. It indicates that there are the different reforming activitiesfor the steam reforming of tar by $\mathrm{Ni}$, Co and Fe. Wang [39] and Ahmed [40] reported that metallic Ni catalyst hasmuch higher reforming activity than metallic Fe. It is possible thatNi metal surface hashigheractivation 
ability for cleavage of $\mathrm{C}-\mathrm{H}$ and $\mathrm{C}-\mathrm{C}$ bonds in the hydrocarbon molecules [10].More interesting, compared with $\mathrm{Ni}$, Co and Fe loadings, the highest $\mathrm{H}_{2}$ yield is obtainedin the case of $\mathrm{Cu}$ loading in this study. It indicates that $\mathrm{Cu}$ loaded CES couldprovide more active sites for the back-spillovers of labile $-\mathrm{OH}, \mathrm{H}$ and $-\mathrm{O}$ specieson it for thesteam reforming of tar.

\subsection{Cu loading amount}

To further understand the activity of Cu-loaded CES on the steam reforming of tar, the effect of $\mathrm{Cu}$ loading amount on the catalytic activity was investigated. $0.25,1,2,5$, and $10 w t \%$ of $\mathrm{Cu}$ weresupported on CES, respectively. Figure 6 shows the yields of $\mathrm{H}_{2}, \mathrm{CO}$, $\mathrm{CH}_{4}$ and $\mathrm{CO}_{2}$ when different concentrations of $\mathrm{Cu}$ loaded $\mathrm{CES}$ are applied. One can see that $1-2 \mathrm{wt} \% \mathrm{Cu}$ loading amount results in the maximum hydrogen yield.Figure7 shows XRD patterns of CES with different $\mathrm{Cu}$ loading amounts. Only the peaks of $\mathrm{CaO}$ can be observed in the XRD pattern of un-doped CES. However, even a little amount of Cu (i.e., 0.25 wt\%) is loaded on CES, the peaks of both $\mathrm{CaO}$ and $\mathrm{Ca}(\mathrm{OH})_{2}$ appear. When the loading amount is higher than $1 \mathrm{wt} \%$, the peaks of calcium copper oxide phase can be detected, and with the increase of $\mathrm{Cu}$ loading amount, theintensity of peaks corresponding to calcium copper oxide also increases, indicating the formation of largercalcium copper oxide particles on CES. It is considered that the formation of calcium copper oxide could stabilize Cu species 
on CES andprovide new active sites for the tar reforming. As a result, $\mathrm{H}_{2}$ yield increases with the increasing of $\mathrm{Cu}$ loading amount from $0.25 \mathrm{wt} \%$ to $1 \mathrm{wt} \%$. However, after the $\mathrm{Cu}$ loading amount is over $2 \mathrm{wt} \%$, the $\mathrm{H}_{2}$ yield gradually decreasesto some extent. It is mainly due to the formations of larger particle of $\mathrm{Cu}$ and calcium copper oxide, which result in the decrease of active sites of the catalyst for contacting tar as well as steam. Herein, the $\mathrm{Cu}$ loading amount from $1 \mathrm{wt} \%$ to $2 \mathrm{wt} \%$ providesthe most opportunity for tar to contact active sites. It is reported that $\mathrm{Cu}$ is less active for the steam reforming of hydrocarbons than $\mathrm{Ni}$ and Co when they are supported on other support [13]. It is possible that the activity of metal modified catalysts could be influenced by the loading amount and especially the interaction between the metal and support. It should be noted that the dispersion properties of metal species on different supports should be different, and some new phases could be generated because of the interaction. In the present study, the active sites should be mainly on $\mathrm{Cu}$ species and the new phases formed between $\mathrm{Cu}$ and support, i.e., $\mathrm{Ca}_{0.828} \mathrm{CuO}_{2}$ as shown in Fig.7.

\subsection{Reusability ofCu-loaded CES}

Figure 8 shows gas yields when $1 \mathrm{wt} \% \mathrm{Cu} / \mathrm{CES}$ catalyst was reused for 5 cycles with regeneration by calcination of it in air at a temperature of $650^{\circ} \mathrm{C}$ for $3 \mathrm{~h}$. It is found that the gas yield,especially for $\mathrm{H}_{2}$ yield, has almost no change and even increase a little more when 
the catalyst is reused for 5 times, indicating that the catalyst has excellent reusability.Moreover, the regenerated catalyst shows a little higher catalytic activity, whichshould be caused by the following two possible reasons. On the one hand,it has been proved that the alkaline elements such as K contained in cedar wood can be evaporated and move to the catalyst layer with tar [10].As such, with the increase of reuse cycle, more potassium could be fixed on the surface of catalyst, which willenhance the catalytic activity.On the other hand, it is reported thatthe presence of $\mathrm{KFeO}_{2}$ in the Fe-based catalyst can maintain a high and long-term activity[33, 34].Similarly, in this study, the formation of copper potassium oxide phaseon the surface of CES should also be benefit for themaintaining ofthe highand long-term activity ofCu/CES catalyst.

\section{Conclusions}

Steam reforming of tar derived from cedar wood over CES as well as copper-loaded CES was investigated in a fixed bed reactor. CES showed a good catalytic activity for production of fuel gases, especially hydrogen gas from the tar reforming. Furthermore, loading of $\mathrm{Fe}, \mathrm{Ni}$, Co or $\mathrm{Cu}$ on CES resulted inhigher catalytic activity. Especially,morefuel gases, especially $\mathrm{H}_{2}$, was produced when using $\mathrm{Cu}$ loaded CES.The optimum $\mathrm{Cu}$ loading amount on CES was found to be 1-2wt\%,which produced the highest yield offuel gases and also exhibited excellent reusability. 


\section{Acknowledgements}

This work is supported by Strategic International Collaborative Research Program (SICORP), Japan Science and Technology (JST), Japan andthe International Joint Research Project of Shanxi Province (No.2015081051and 2015081052), China.

\section{References}

[1] Zhao B, Zhang X, Chen L, Qu R, Meng G, Yi X, et al. Steam reforming of toluene as model compound of biomass pyrolysis tar for hydrogen. Biomass Bioenergy 2010; 34:140-4.

[2] Virginie M, Courson C, Kiennemann A, Toluene steam reforming as tar model molecule produced during biomass gasification with an iron/olivine catalyst. Comptes Rendus Chimie 2010;13:1319-25.

[3] Kim SC, Lim MS, Chun YN. Hydrogen-rich gas production from a biomass pyrolysis gas by using a plasmatron. Int J Hydrogen Energy 2013;38:14458-66.

[4] Nunnally T, Tsangaris A, Rabinovicha A, Nirenberga G, Chernetsa I, Fridman A. Gliding arc plasma oxidative steam reforming of a simulated syngas containing naphthalene and toluene. Int J Hydrogen Energy 2014;39:11976-89.

[5] Chang A, Chang L, Tsai C, Chan Y. Steam reforming of gasification-derived tar for syngas production. Int J Hydrogen Energy 2014;39:19376-81. 
[6] Jiang L, Hu S, Wang Y, Su S, Sun L, Xu B, He L, Xiang J. Catalytic effects of inherent alkali and alkaline earth metallic species on steam gasification of biomass. Int $\mathrm{J}$ Hydrogen Energy 2015;40:15460-69.

[7] Guan G, Kaewpanha M, Hao X, Zhu A, Kasai Y, Kakuta S, Kusakabe K, Abudula A. Steam reforming of tar derived from lignin over pompom-like potassium-promoted iron-based catalysts formed on calcined scallop shell. Bioresource Technol2013;139:280-4.

[8] Guan G, Kaewpanha M, Hao X, Wang Z, Cheng Y, Kasai Y, Abuliti A. Promoting effect of potassium addition to calcined scallop shell supported catalysts for the decomposition of tar derived from different biomass resources. Fuel 2013;109:241-7.

[9] Kaewpanha M, Guan G, Ma Y, Hao X, Zhang Z, Reubroychareon P, Kusakabe K, Abudula A. Hydrogen production by steam reforming of biomass tar over biomass char supported molybdenum carbide catalyst. Int J Hydrogen Energy 2015;40:7974-82.

[10] Guan G, Chen G, Kasai Y, Lim EWC, Hao X, Kaewpanha M, Abuliti A, Fushimi C, Tsutsumi A. Catalytic steam reforming of biomass tar over iron- or nickel-based catalyst supported on calcined scallop shell. Appl Catal B: Environ 2012; 115-116:159-68.

[11] Oemar U, Ang PS, Kawi S. Promotional effect of Fe on perovskite $\mathrm{LaNi}_{\mathrm{x}} \mathrm{Fe}_{1-\mathrm{x}} \mathrm{O}_{3}$ catalyst for hydrogen production via steam reforming of toluene. Int $\mathrm{J}$ Hydrogen 
Energy 2013;38:5525-34.

[12] Mun TY, Cho MH, Kim JS. Air gasification of dried sewage sludge in a two-stage gasifier. Part 3: Application of olivine as a bed material and nickel coated distributor for the production of a clean hydrogen-rich producer gas. Int J Hydrogen Energy 2014;39:5525-34.

[13] Li D, Koike M, Chen J, Nakagawa Y, Tomishige K. Preparation of Ni-Cu/Mg/Al catalysts from hydrotalcite-like compounds for hydrogen production by steam reforming of biomass tar. Int J Hydrogen Energy 2014;39:10959-70.

[14] Gao N, Liu S, Han Y, Xing C, Li A. Steam reforming of biomass tar for hydrogen production over NiO/ceramic foam catalyst. Int J Hydrogen Energy 2015;40:7983-90.

[15] Rhyner U, Edinger P, Schildhauer TJ, Biollaz SMA. Experimental study on high temperature catalytic conversion of tars and organic sulfur compounds. Int J Hydrogen Energy 2014;39:4926-37.

[16] Li D, Tamura M, Nakagawa Y, Tomishige K. Metal catalysts for steam reforming of tar derived from the gasification of lignocellulosic biomass. Bioresource Technol 2015;178: 53-64.

[17] Li D,Wang L, Koike M, Nakagawa Y, Tomishige K. Steam reforming of tar from pyrolysis of biomass over $\mathrm{Ni} / \mathrm{Mg} / \mathrm{Al}$ catalysts prepared from hydrotalcite-like precursors. Appl Catal B: Environ 2011;102:528-538. 
[18] Wang L, Li D, Watanabe H, Tamura M, Nakagawa Y, Tomishige K. Catalytic performance and characterization of $\mathrm{Co} / \mathrm{Mg} / \mathrm{Al}$ catalysts prepared from hydrotalcite-like precursors for the steam gasification of biomass. Appl Catal B: Environ 2014;150-151:82-92.

[19] Koike M, Li D, Nakagawa Y, Tomishige K. A highly active and coke-resistant steam reforming catalyst comprising uniform nickel-iron alloy nanoparticles. ChemSusChem 2012;5(12):2312-4.

[20] Li D, Koike M, Wang L, Nakagawa Y, Xu Y, Tomishige K. Regenerability of Hydrotalcite-Derived Nickel-Iron Alloy Nanoparticles for Syngas Production from Biomass Tar. ChemSusChem 2014;7(2):510-22.

[21] Koike M, Li D, Watanabe H, Nakagawa Y, Tomishige K. Comparative study on steam reforming of model aromatic compounds of biomass tar over $\mathrm{Ni}$ and $\mathrm{Ni}-\mathrm{Fe}$ alloy nanoparticles. Appl Catal A: Gen 2015;506:151-62.

[22] Watanabe H, Li D, Nakagawa Y, Tomishige K, Watanabe MM. Catalytic gasification of oil-extracted residue biomass of Botryococcus braunii. Bioresource Technol 2015;191:452-9.

[23] Li D, Ishikawa C, Koike M, Wang L, Nakagawa Y, Tomishige K. Production of renewable hydrogen by steam reforming of tar from biomass pyrolysis over supported Co catalysts.Int J Hydrogen Energy 2013;38:3572-81. 
[24] D’Orazio A, Di Carlo A, Dionisi N, Dell’Era A, Orecchini F. Toluene steam reforming properties of $\mathrm{CaO}$ based synthetic sorbents for biomass gasification process. Int $\mathrm{J}$ Hydrogen Energy 2013;38:13282-92.

[25] Zamboni I, Zimmermann Y, Kiennemann A, Courson C. Improvement of steam reforming of toluene by $\mathrm{CO}_{2}$ capture using $\mathrm{Fe} / \mathrm{CaO}-\mathrm{Ca}_{12} \mathrm{Al}_{14} \mathrm{O}_{33}$ bi-functional materials. Int J Hydrogen Energy 2015;40:5297-304.

[26] Di Carlo A, Borello D, Sisinni M, Savuto E, Venturini P, Bocci E, Kuramoto K. Reforming of tar contained in a raw fuel gas from biomass gasification using nickel-mayenite catalyst. Int J Hydrogen Energy 2015;40:9088-95.

[27] Ashok J, Kawi S. Steam reforming of toluene as a biomass tar model compound over $\mathrm{CeO}_{2}$ promoted $\mathrm{Ni} / \mathrm{CaO}-\mathrm{Al}_{2} \mathrm{O}_{3}$ catalytic systems. Int $\mathrm{J}$ Hydrogen Energy 2013;38:13938-49.

[28] Sirisomboonchai S, Abuduwayiti M, Guan G, Samart C,Abliz S, Hao X, Kusakabe K, Abudula A. Biodiesel production from waste cooking oil using calcined scallop shellas catalyst. Energy Convers Manage 2015;95:242-7.

[29] Di Felice L, Courson C, Niznansky D, Foscolo PU, Kiennemann A.Biomass gasification with catalytic tar reforming: a model study into activity enhancement of calcium- and magnesium-oxide-based catalytic materials by incorporation of iron. Energy Fuels 2010;24:4034-45. 
[30]Czernik S, French R, Feik C, Chornet E. Hydrogen by catalytic steam reforming of liquid from biomass thermoconversion processes. Ind Eng Chem Res 2002;41:4209-15.

[31]Polychronopoulou K, Bakandritsos A, Tzitzios V, Fierro JLG, Efstathiou AM. Absorption-enhanced reforming of phenol by steam over supported Fe catalysts. J Catal 2006;241:132-48.

[32]Stevens JRW, Shami A, Carpenter S, Siriwardance R.Sorption-enhanced water gas shift reaction by sodium-promoted calcium oxides. Fuel 2010;89:1280-6.

[33] Han C, Harrison DP.Simultaneous shift reaction and carbon dioxide separation for the direct production of hydrogen. Chem Eng Sci 1994;49:5875-83.

[34]Harrison DP. Sorption-enhanced hydrogen production: A review. Ind Eng ChemRes 2008;47:6486-501.

[35] Karnjanakom S, Guan G, Asep B, Du X, Hao X, Samart C, Abudula A. Catalytic steam reforming of tar derived from steam gasification of sunflower stalk over ethylene glycol assisting prepared Ni/MCM-41. Energy Conver Manag 2015;98:359-68.

[36] Kaewpanha M, Guan G, Hao X, Wang Z, Kasai Y, Kakuta S, Kusakabe K, Abudula A. Steam reforming of tar derived from the steam pyrolysis of biomass over metal catalyst supported on zeolite. J Taiwan Institute Chem Eng 2013; 44:1022-6.

[37] Polychronopoulou K, Costa CN, Efstathiou AM. The role of oxygen and hydroxyl support species on the mechanism of $\mathrm{H} 2$ production in the steam reforming of phenol 
over metal oxide-supported-Rh and -Fe catalysts. Catal Today 2006;112:89-93.

[38]Polychronopoulou K, Fierro JLG, Efstathiou AM.The phenol steam reforming reaction over MgO-based supported Rh catalysts. J Catal 2004;228:417-32.

[39] Wang L, Li D, Koike M, Koso S, Nakagawa Y, Xu Y, Tomishige K.Catalytic performance and characterization of Ni-Fe catalysts for the steam reforming of tar from biomass pyrolysis to synthesis gas. Appl Catal A: Gen 2011;392:248-55.

[40]Ahmed S, Aitani A, Rahman F, Al-Dawood A, Al-Muhaish F. Decomposition of hydrocarbons to hydrogen and carbon. Appl Catal A: Gen 2009;359:1-24. 


\section{Figure captions}

Fig. 1 XRD patterns of egg shell calcined at different temperatures. Crystalline phases:

$(\bullet) \mathrm{CaCO}_{3} ;(\diamond) \mathrm{CaO}$;

Fig. 2 TGA profile of egg shell.

Fig. 3Images of egg shell calcined at different temperatures. (a) SEM image of the surface of original egg shell; (b) SEM image of the surface of egg shell calcined at $900^{\circ} \mathrm{C}$.

Fig. 4Gas yield over different CES and commercial $\mathrm{CaO}$ at $650^{\circ} \mathrm{C}$.

Fig. 5 Gas yields over CES loaded with different metals at $650{ }^{\circ} \mathrm{C}$.

Fig. 6 Gas yields over CESloaded with different $\mathrm{Cu}$ loading amounts at $650{ }^{\circ} \mathrm{C}$.

Fig. 7 XRD patterns of Cu/CES catalysts with different Cu loading amounts. Crystalline phases: (•) $\mathrm{Ca}_{0.828} \mathrm{CuO}_{2} \quad(\boldsymbol{\Delta}) \mathrm{Ca}(\mathrm{OH})_{2} \quad(\bullet) \mathrm{CaO}$

Fig. 8Reusability of $1 \mathrm{wt} \% \mathrm{Cu} / \mathrm{CES}$ catalyst for the steam reforming of tar derived from cedar wood. 
Fig. 1

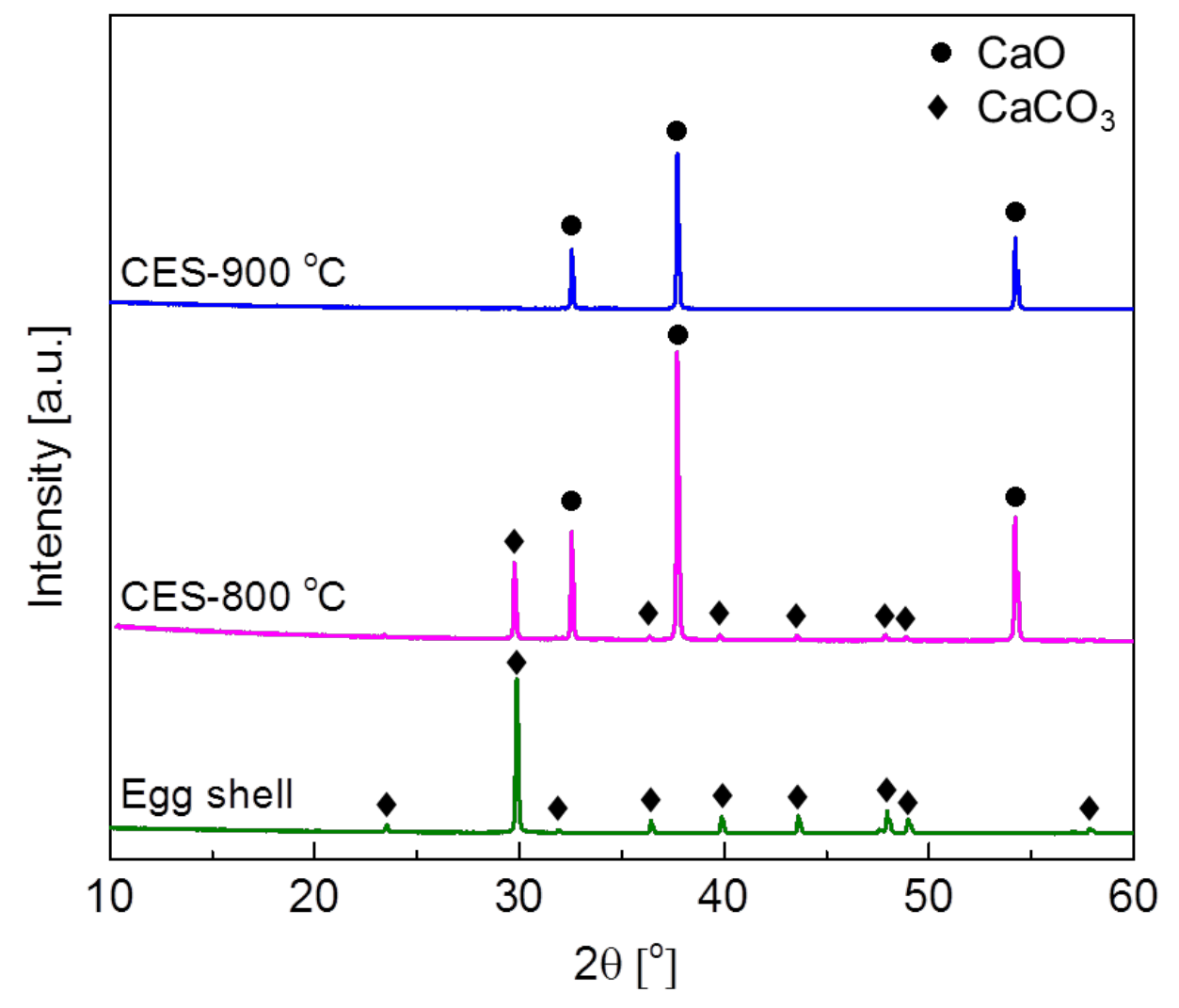


Fig. 2

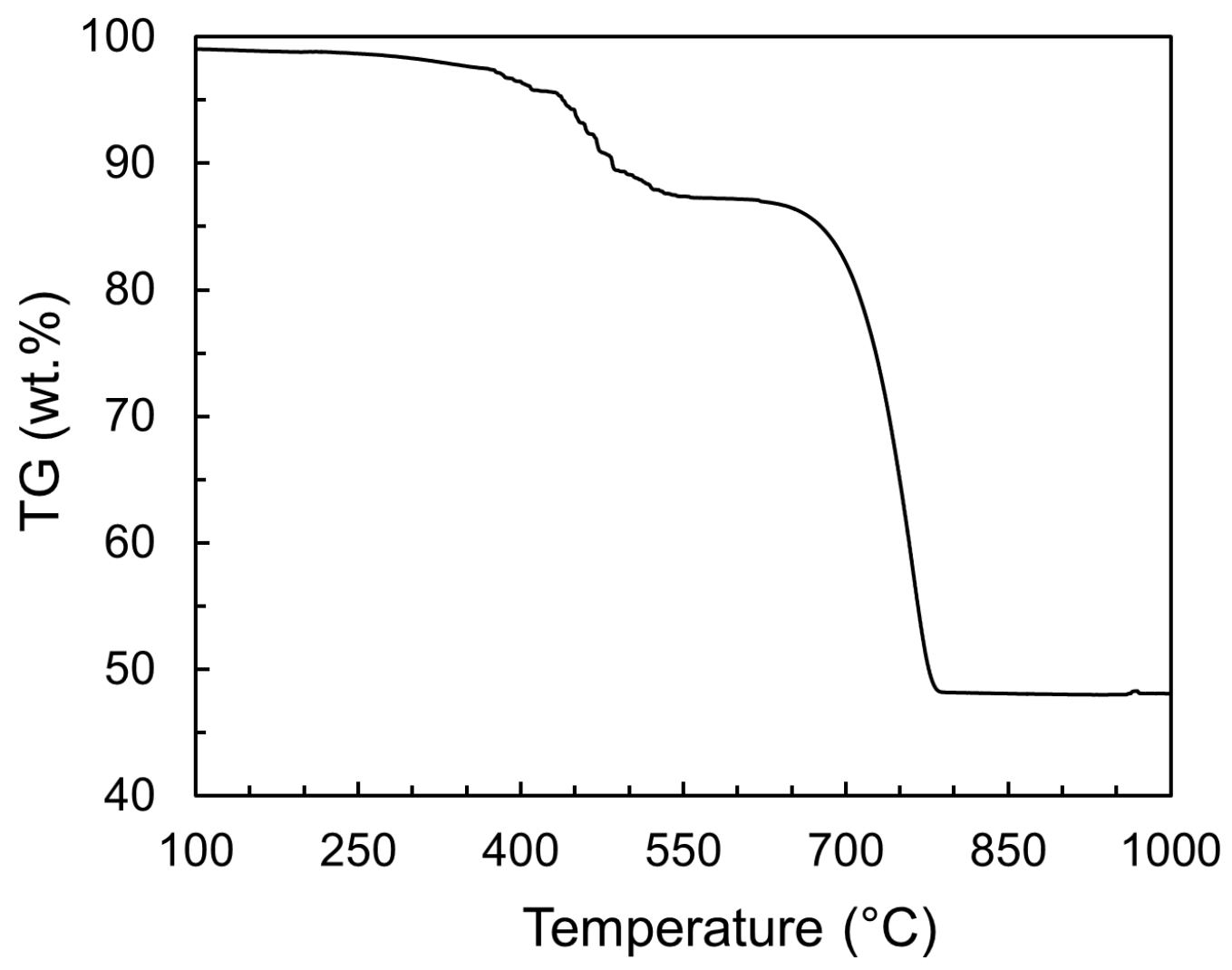


Fig. 3
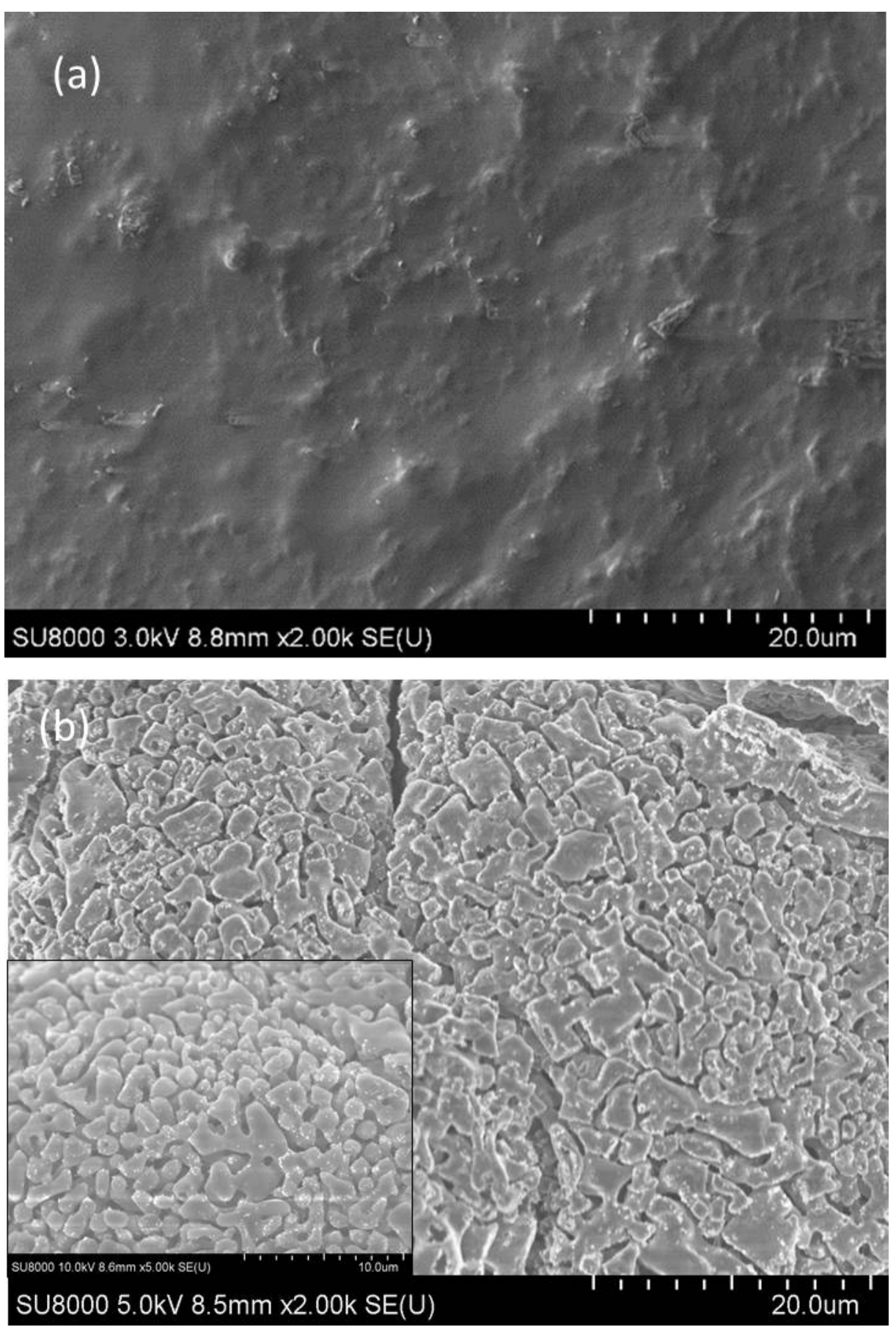
Fig. 4

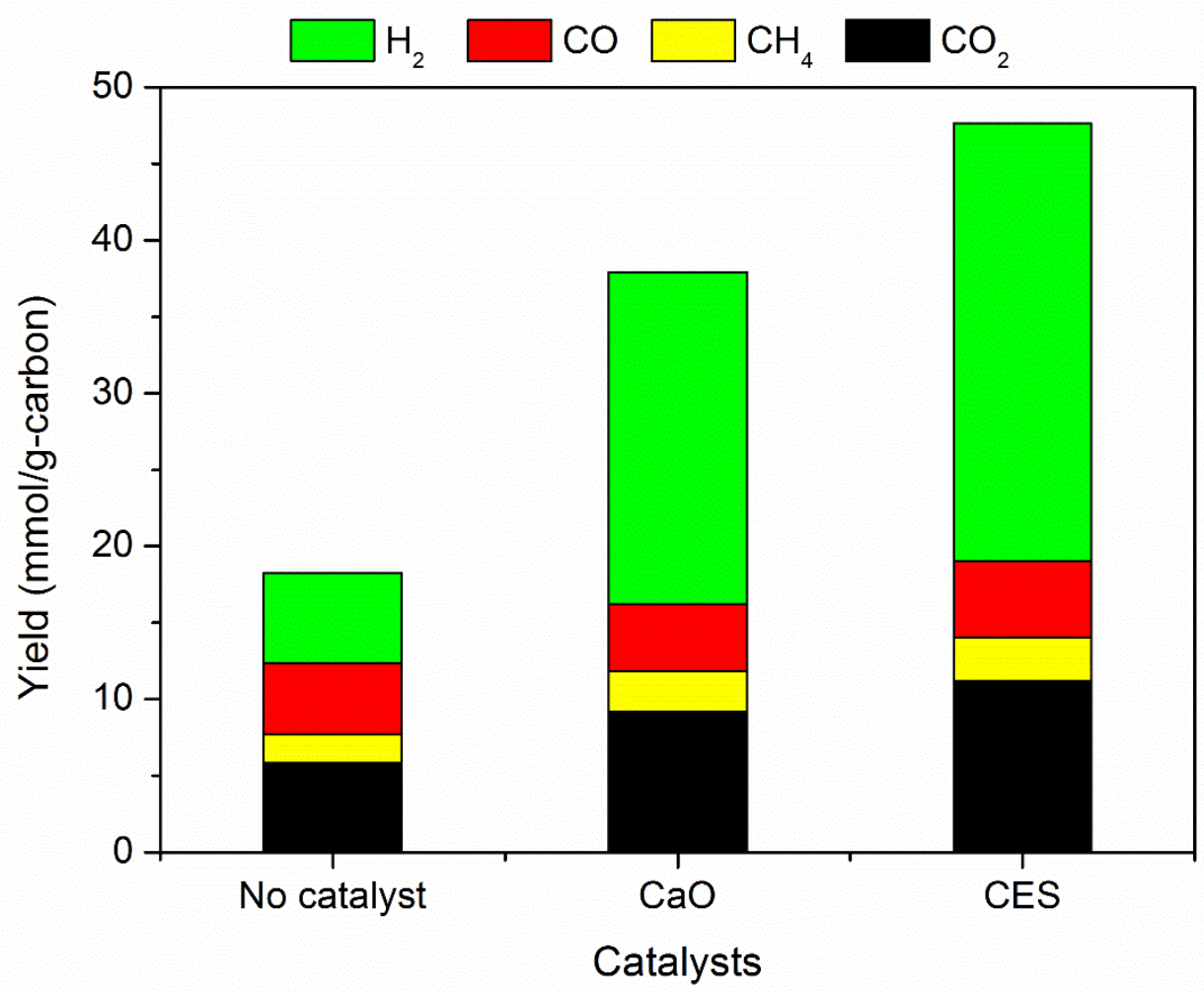


Fig. 5

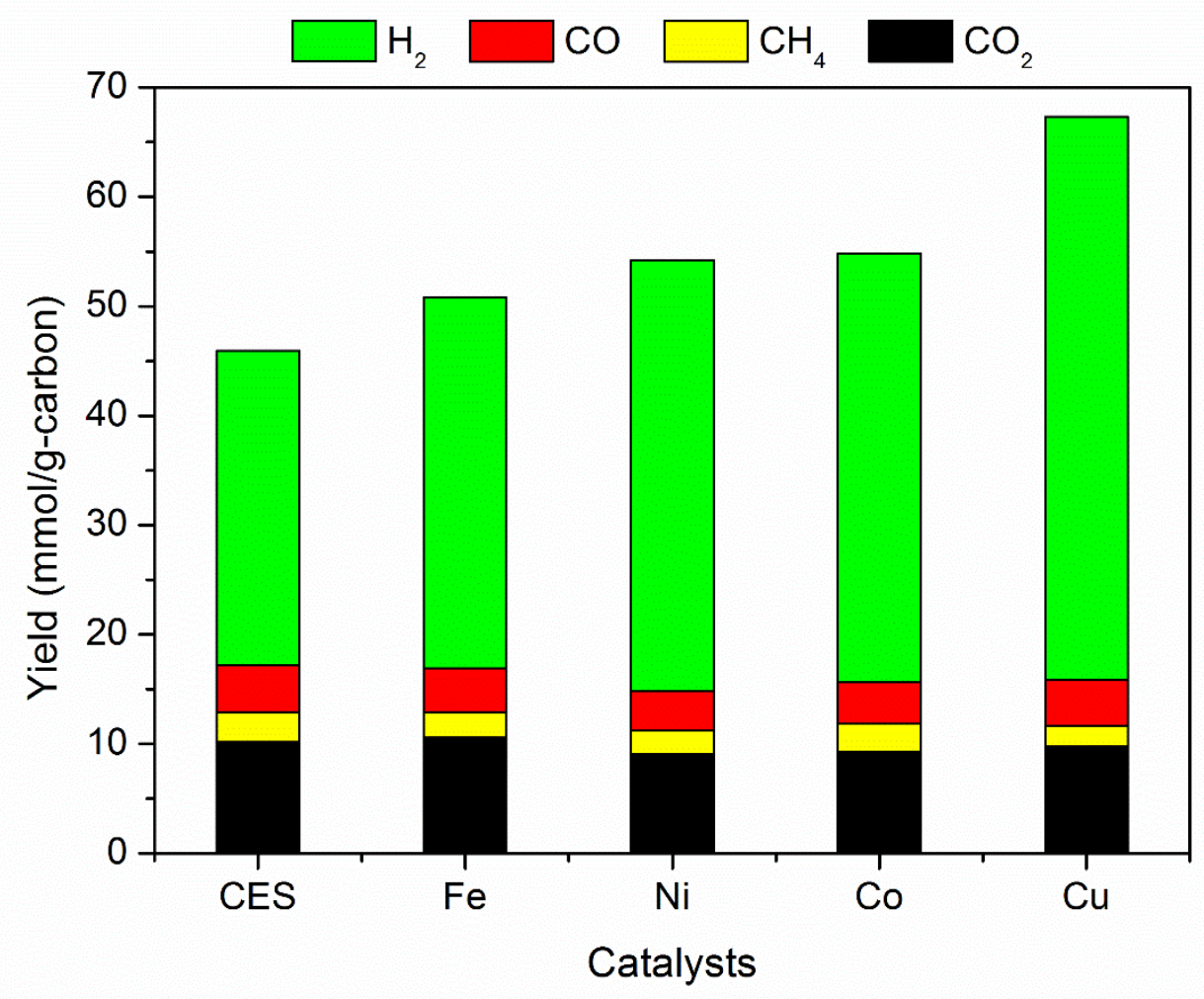


Fig. 6

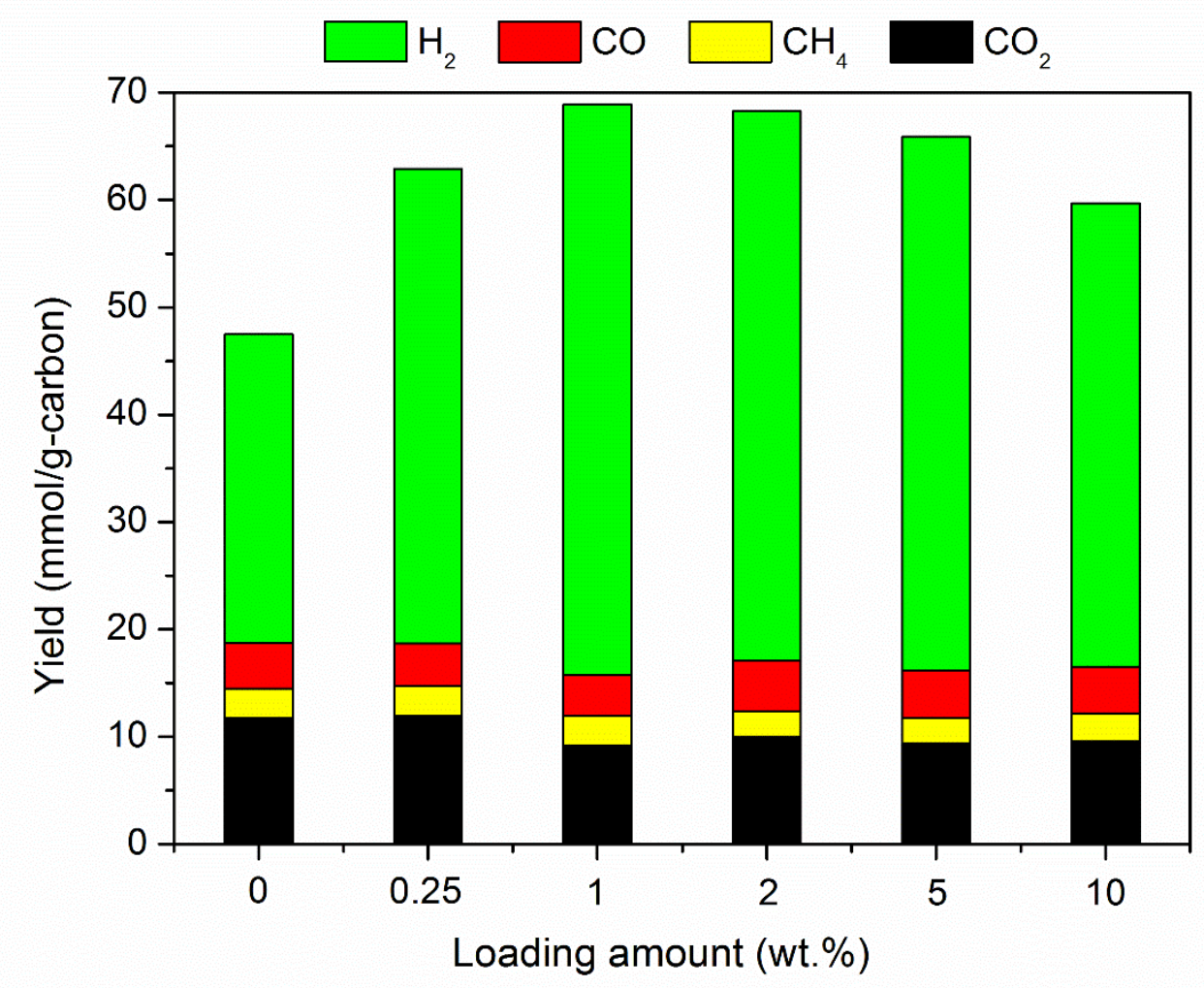


Fig. 7
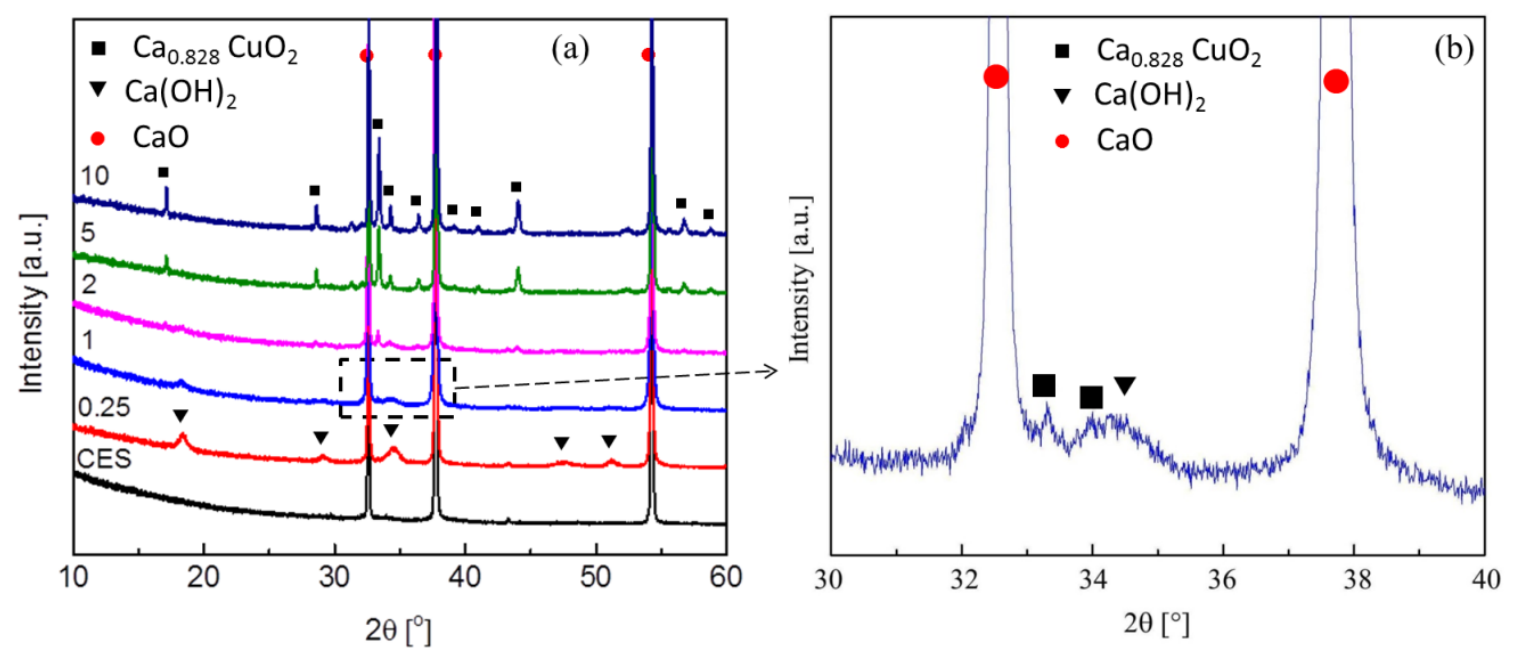
Fig. 8

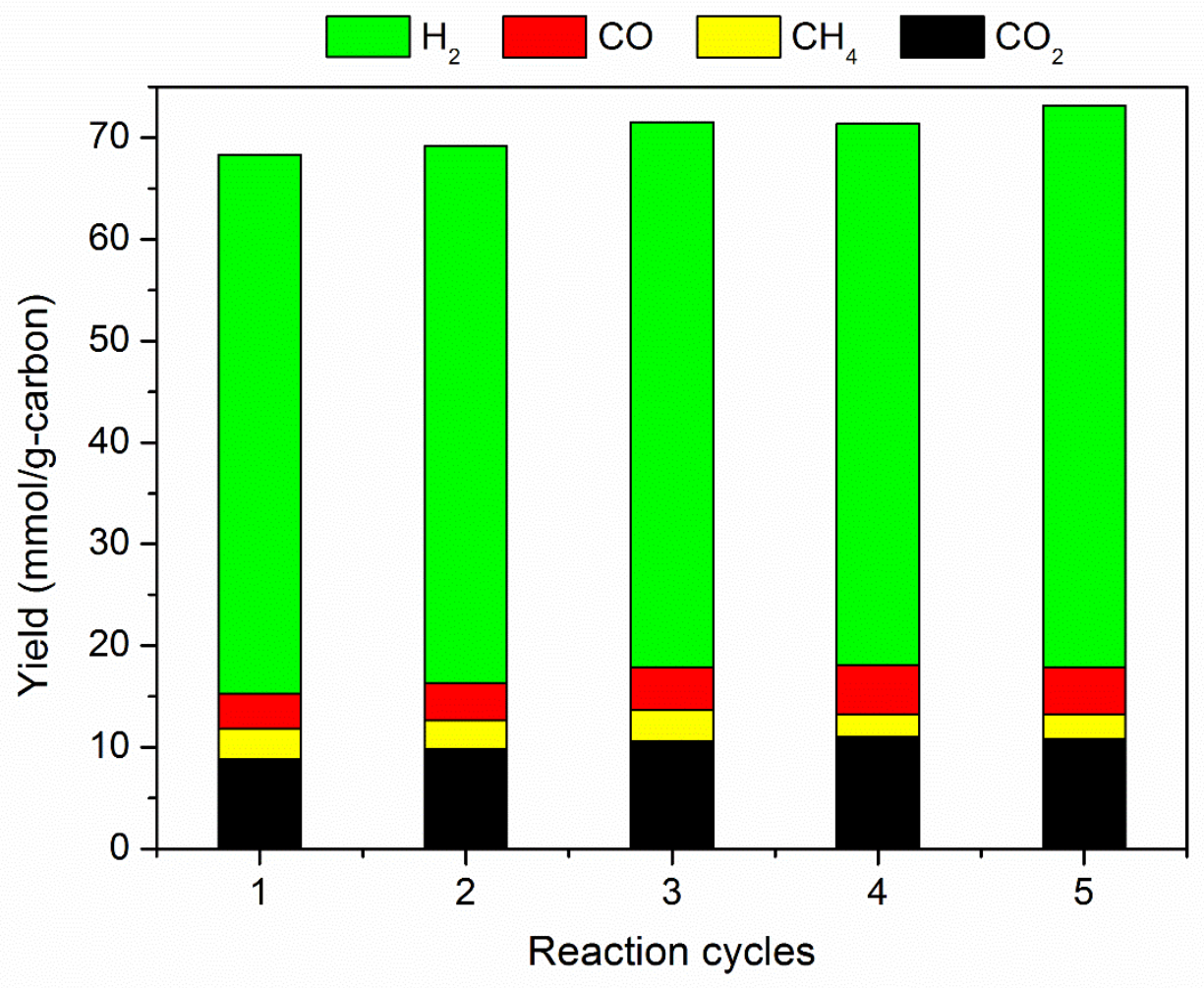

